\title{
Financial Deepening in the CFA Franc Zone: The Role of Institutions
}

\author{
Raju Jan Singh, Kangni Kpodar, and \\ Dhaneshwar Ghura
}




\title{
IMF Working Paper
}

\author{
African Department \\ Financial Deepening in the CFA Franc Zone: \\ The Role of Institutions
}

Prepared by Raju Jan Singh, Kangni Kpodar, and Dhaneshwar Ghura ${ }^{1}$

May 2009

\begin{abstract}
During the 1980s and early 1990s many Sub-Saharan African (SSA) countries undertook reforms to promote financial sector deepening. Nevertheless, financial sectors in SSA countries remain among the shallowest in the world and, within Sub-Saharan Africa, financial depth in the CFA franc zone is even more limited. This paper sets out to investigate empirically factors that may explain why financial depth in the CFA franc zone is shallower than in the rest of SSA using panel data for a sample of 40 countries for 1992-2006. The results indicate that the gap in financial development between the CFA franc zone countries and the rest of SSA can be explained by differences in institutional quality (e.g., availability of credit information, and strength and enforcement of property rights), variables that policy makers can influence.
\end{abstract}

\section{This Working Paper should not be reported as representing the views of the IMF.}

The views expressed in this Working Paper are those of the author(s) and do not necessarily represent those of the IMF or IMF policy. Working Papers describe research in progress by the author(s) and are published to elicit comments and to further debate.

JEL Classification Numbers: G21, G28, O16

Keywords: Financial deepening CFA Franc zone.

Author’s E-Mail Address: rsingh2@imf.org; kkpodar@imf.org; dghura@imf.org

\footnotetext{
${ }^{1}$ This paper was presented at the conference on Financial Sector Development in the CEMAC, Yaoundé, June 3-4, 2008. We wish to thank Anne Grant and Thierry Tressel, as well as seminar participants at the African Department, for useful comments.
} 


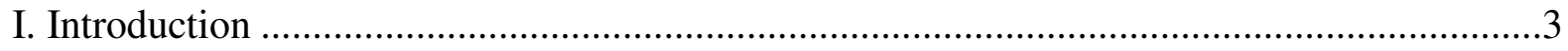

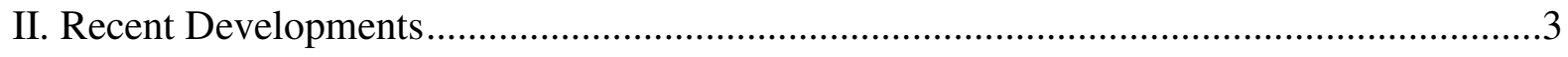

III. Theoretical Background and Review of the Literature .............................................6

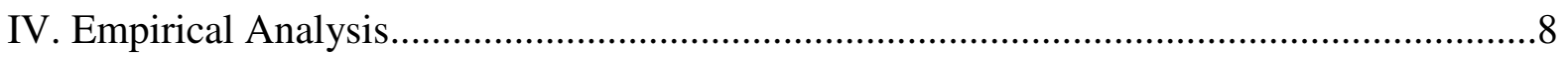

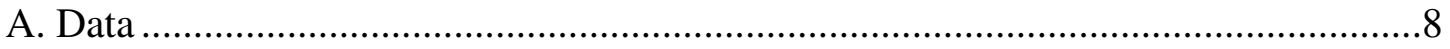

B. Methodology and Main Results ...............................................................

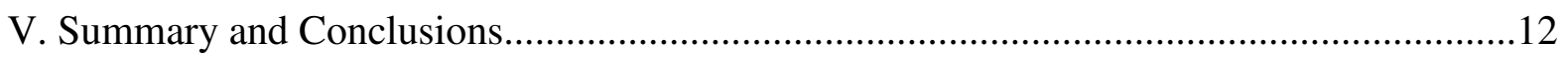

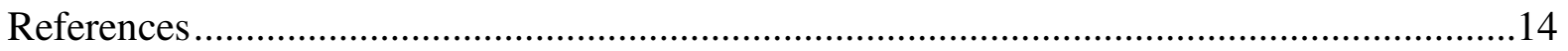




\section{INTRODUCTION}

During the 1980s and early 1990s, many Sub-Saharan African (SSA) countries undertook reforms to deepen their financial sectors. They liberalized interest rates, phased out directed credit, moved to indirect monetary policy instruments, restructured and privatized banks, and reinforced banking sector supervision and microfinance. ${ }^{2}$ However, these reforms had mixed results. Financial sectors in SSA countries remain among the shallowest in the world and, within sub-Saharan Africa, they are even shallower in the CFA franc zone.

This paper sets out to empirically investigate factors that may explain why financial sectors in the CFA franc zone are less deep even than in the rest of SSA. Recent studies have emphasized the linkage between legal institutions and financial development. Empirical work has shown that countries whose legal systems are based on the English tradition tend to have deeper financial markets, while the French legal traditions seems to hinder financial development. Although these studies have not focused explicitly on Africa, the implication would be that financial deepening in CFA franc countries could be hampered by their cultural heritage.

This paper contributes to the literature in two ways. First, it explores the possible influence of legal traditions explicitly in SSA using panel data for a sample of 40 countries for 1992-2006. Second, the paper challenges the view that legal heritage is time-invariant and policy-independent. The results indicate that the gap in financial development between the countries of the CFA franc zone and the rest of SSA can be explained by differences in institutional quality (e.g., availability of credit information, and strength and enforcement of property rights), variables that policy makers can influence.

The paper is structured as follows: Section II presents some stylized facts about recent developments in the financial sector in SSA; Section III provides a brief review of the literature; Section IV discusses the data, methodology, and main empirical results; and Section V concludes the paper.

\section{RECENT DEVELOPMENTS}

Financial sectors in SSA countries (measured as credit to the private sector in terms of GDP) are among the shallowest in the world. On average, in 2006, credit to the private sector represented the equivalent of 16 percent of GDP in SSA countries, while the same ratio was above 35 percent in the rest of the developing world (low-income and middle-income countries). Focusing on sub-Saharan Africa more closely, financial sectors in CFA franc countries are even shallower. On average, in 2006, credit to the private sector in terms of GDP amounted to about 14 percent in the Western African Economic and Monetary Union (WAEMU) and 7 percent in the Central African Economic and Monetary Community (CEMAC), compared with 19 percent for the rest of sub-Saharan Africa.

\footnotetext{
${ }^{2}$ See, for example, Mehran and others (1998) for a description of the reforms.
} 


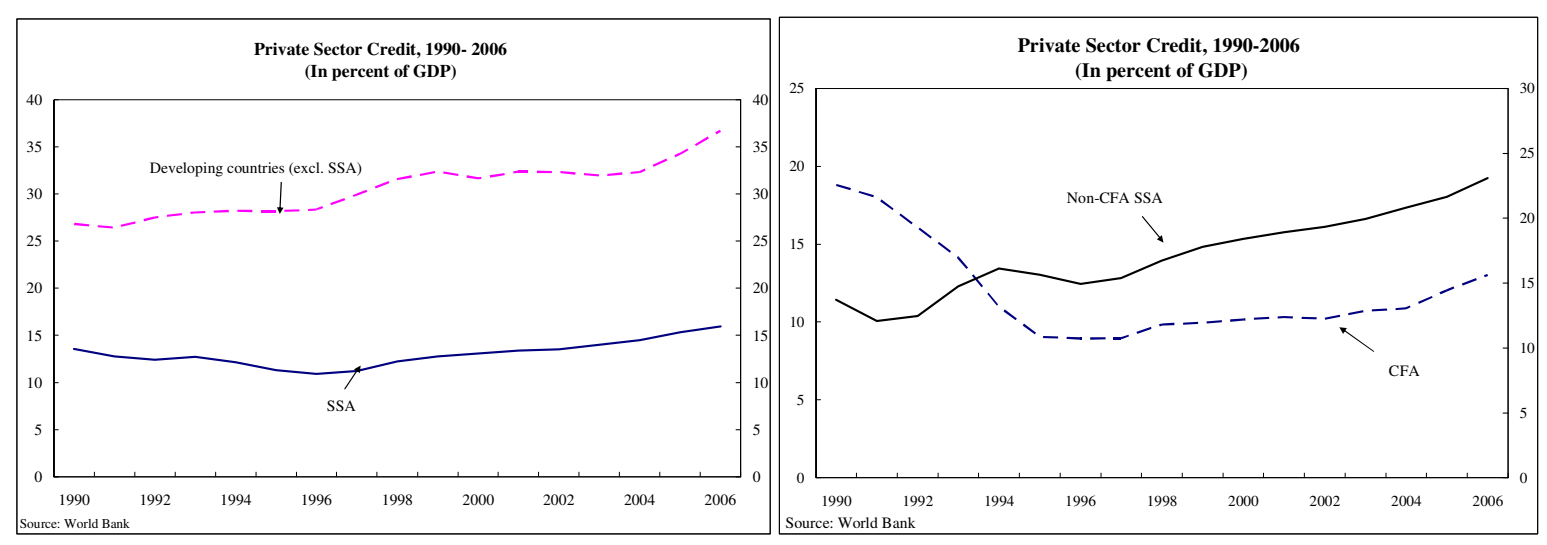

CFA franc countries seem, however, to have undertaken similar efforts to liberalize and reform their financial sectors. As elsewhere in the continent, bank restructuring took place in the late 1980s and was followed by a strengthening of bank supervision with the creation in 1991 of a single supervisory institution in each of the two CFA franc sub-zones. ${ }^{3}$ So what could explain the relative shallowness of financial sectors in the CFA franc countries?

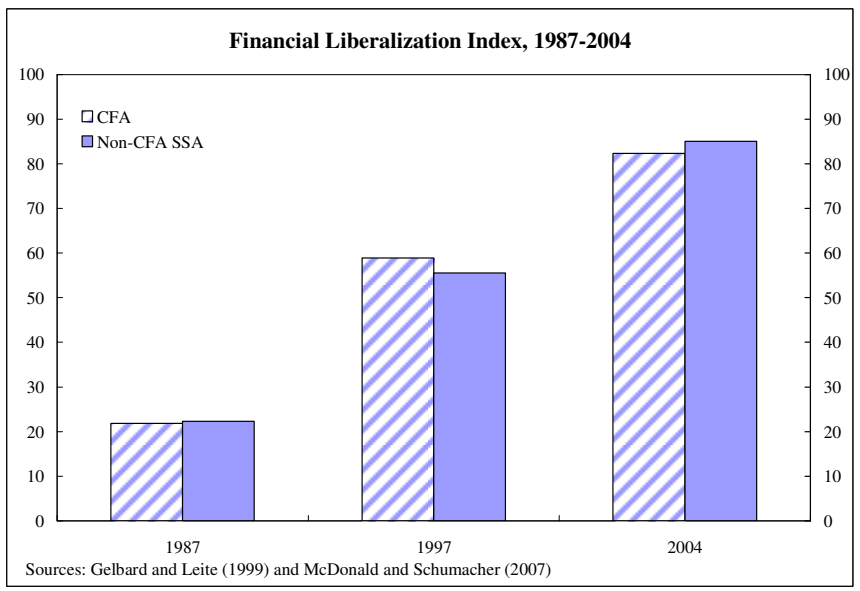

There is a growing body of literature arguing that macroeconomic stability and financial liberalization, while necessary, are not sufficient conditions for enhancing financial sector deepening and should be accompanied by other institutional reforms. In particular, recent research suggests that insufficient legal protection of creditor rights and information asymmetries about borrowers' ability and willingness to repay debts could explain why some financial markets remain shallow. How do the CFA franc countries compare in this regard?

According to these studies, the ability of borrowers to provide adequate financial statements is essential to encourage the expansion of credit. Better accounting and auditing would therefore be a key requirement. In many SSA countries, however, the accounting profession is not well regulated, and the quality of accounts vary widely, hampering transparency. OHADA (the Organisation for the Harmonization of Business Law in Africa) and the WAEMU Council of Ministers adopted a uniform accounting system in 2001, but have had

\footnotetext{
${ }^{3}$ Large bank restructurings took place in Senegal (1988-89), Côte d'Ivoire (1988-89), Benin (1988-89), Mali (1989), Niger (1989-90), and Cameroon (1990-97).
} 
trouble implementing it. ${ }^{4}$ Furthermore, lack of a standard for auditing practices raises serious concerns about the quality of financial statement audits.

The dissemination of the information available seems also problematic. In advanced countries, databases centralizing information on borrowers are often established by the private sector or maintained by central banks. These credit information registries collect information on the standing of borrowers in the financial system and make it available to lenders. This system improves transparency, rewarding good borrowers and increasing the cost of defaulting. Despite efforts to set up public credit information registries in CFA franc countries, however, their coverage is still minimal.
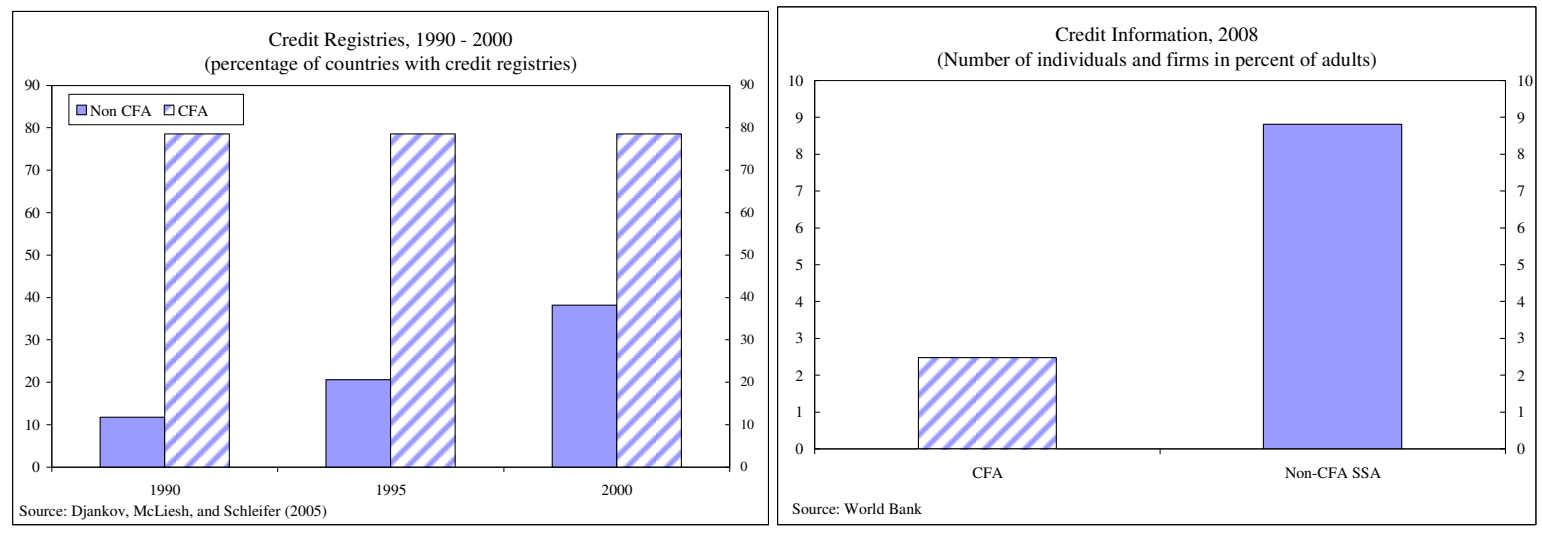

Property rights in the CFA franc zone have also weakened over the past decade. The regional OHADA legal framework has led to a number of improvements, but there are significant deficiencies in its implementation. Debt collection and foreclosure on collateral are inefficient because of uncertainties in each country's civil procedures, and inadequate capacity and problems of governance in the judicial systems. Court proceedings are lengthy and unpredictable. These problems are common to many SSA countries, but seem more acute in the CFA franc zone. According to the World Bank, enforcement costs there represented on average more than 45 percent of a loan in 2008 compared with 30 percent in the rest of SSA. In Burkina Faso the costs amounted to 95 percent and in the Central African Republic to 72 percent, in striking contrast to less than 9 percent in Mauritius or 12 percent in South Africa.

\footnotetext{
${ }^{4}$ The accounting framework includes accounting standards, and a standardization and updating of procedures to be implemented with the assistance of the West African Accounting Council. The Council, however, only met once in 2004 and the technical committees have never met.
} 


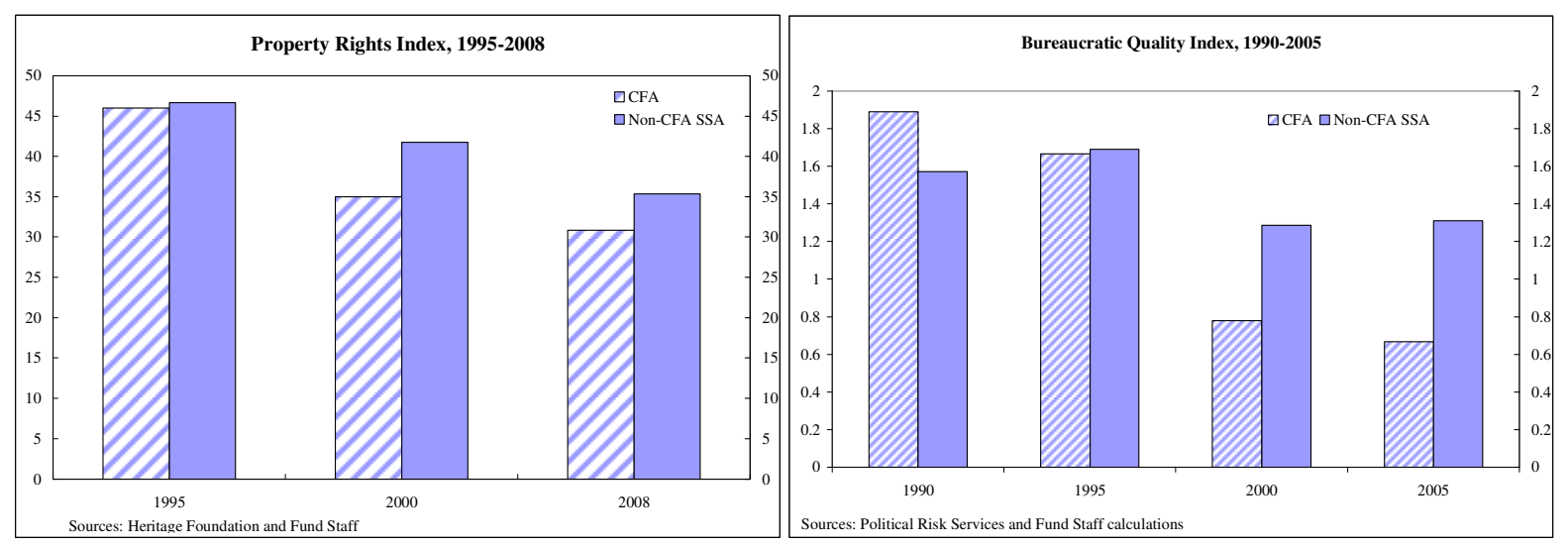

Therefore, as McDonald and Schumacher (2007) and Tressel and Detragiache (2008) have pointed out, while the financial liberalization of the late 1980s and early 1990s was necessary, it may not have been sufficient. Efforts to establish the conditions for the financial market to function may have fallen short, particularly with respect to the system's ability to gather information and use collateral. Improvements in information collection and dissemination, as well as in the legal and judicial framework, would be essential to creating an environment more conducive to credit expansion.

\section{TheORETICAL BACKgROUND AND REVIEW OF THE LiteratURE}

Financial institutions operate in settings where complete information is often not available. Entrepreneurs seeking financing normally have more information about their projects than their banks. In such a setting, projects that may differ with respect to their probability of success are indistinguishable from the viewpoint of a financial institution. This information asymmetry requires a screening effort in order for banks to grant loans only to the most promising projects.

The lender cannot rely simply on increasing the interest rate, however. As Stiglitz and Weiss (1981) demonstrated, increases in the interest rate charged on loans may adversely affect the pool composition of borrowers. For a given expected return, an increase in interest rates will induce low-risk projects to drop out first, keeping only the riskier ones in the pool.

Lenders could require collateral instead. By requiring collateral, the lender imposes a cost on the entrepreneur in case of default. As the probability of failure is greater for high-risk projects, the same amount of collateral will reduce the expected profit of these projects by more than that of less risky ones. Bester (1985) demonstrated that lenders could design attractive contracts for the various qualities of borrowers, leading to perfect sorting. Alternatively, fund providers could invest in gathering additional information on projects. This information will lead to a better perception of the probability of success attached to a given project (Devinney, 1986; Singh, 1994, 1997).

Against this backdrop, the empirical literature has examined factors beyond the level of economic development to explain the extent of a country's financial deepening, looking variables that influence the degree of information asymmetries. In this regard, 
macroeconomic variables like inflation as well as legal aspects have attracted particular attention.

Huybens and Smith $(1998,1999)$ suggest that inflation may aggravate asymmetries of information in credit markets, reducing the real rate of return and the volume of credit. Consistent with these views, Boyd, Levine, and Smith (2001), Detragiache, Gupta, and Tressel (2005), and Dehesa, Druck, and Pleckhanov (2007) find inflation to be negatively associated with measures of financial depth.

The law and finance literature focuses on the role of legal institutions (especially the protection of private property rights) in explaining international differences in financial development. In countries where legal systems enforce private property rights, support private contracts, and protect the legal rights of investors, lenders would be more willing to finance firms. Acemoglu and Johnson (2005), Cottarelli, Dell' Ariccia, and Vladkova-Hollar (2003), Dehesa, Druck, and Plekhanov (2007), McDonald and Schumacher (2007), and Tressel and Detragiache (2008) find that stronger creditor rights tend to promote financial development.

In this regard, a country's legal origin has been shown to be an important determinant of both creditor rights and private credit (La Porta et al. 1998). This literature distinguishes four main legal origins: English, French, German, and Nordic. The English legal origin includes the common law of England, and its former colonies, such as the United States, Australia, and Canada. The French legal origin covers the civil law of France, countries Napoleon conquered (including Portugal and Spain), and their former colonies. The German legal origin includes not only the laws of the Germanic countries in Central Europe, but also countries in East Asia where German law was adopted. ${ }^{5}$ The Nordic legal origin refers to the laws of the four Scandinavian countries. La Porta and others (1998) find countries with an English legal origin to have deeper financial markets than others: the French legal tradition appears to hinder financial development.

Enforcement of rules and rights also matters to financial development. Speedier enforcement of contracts is associated with deeper credit markets (Detragiache, Gupta, and Tressel, 2005; McDonald and Schumacher, 2007). Similarly, poor governance may increase the cost of doing business and create uncertainty about property rights. Detragiache, Gupta, and Tressel (2005) and McDonald and Schumacher (2007) find that countries with governance issues have shallower financial sectors.

Finally, efficient exchange of information can reduce the cost of screening borrowers. Credit agencies, for instance, could collect and disseminate information on credit histories. Djankov, McLiesh, and Shleifer (2005), as well as McDonald and Schumacher (2007) show that information sharing is associated with greater financial development. Furthermore, among the many business environment indicators, the availability of credit information and

\footnotetext{
${ }^{5}$ This group includes China, Japan, Korea, and Taiwan (Djankov, McLiesh, and Shleifer, 2005)
} 
coverage of credit registries are associated with deeper credit markets (Detragiache, Gupta, and Tressel, 2005).

\section{EMPIRICAL ANALYSIS}

\section{A. Data}

Financial development is a complex process involving a number of intermediaries and could be captured by a variety of indicators. The empirical literature has typically used a banking indicator, such as the level of credit to the private sector in terms of GDP. This paper adopts this approach. The econometric analysis uses panel data for 40 SSA countries, of which 14 belong to the CFA franc zone. The data are averaged over five-year periods from 1992 to $2006 .{ }^{6}$

Regarding the right-side variables, the financial liberalization index is constructed for SSA countries by McDonald and Schumacher (2007) building on an earlier study by Gelbard and Leite (1999). This aggregate index is between 0 and 100, and captures whether or not interest rates are liberalized, the number of years real lending and deposit rates have been positive, the existence of a significant informal financial sector and directed credit allocation mechanisms.

The legal variables come from various sources. The property rights index bounded between 0 and 100 is compiled yearly by the Heritage Foundation. It measures the ability of individuals to accumulate private property, secured by clear laws that the state fully enforces.

The information sharing index, a dummy variable recording the presence of either public or private credit registries, is taken from Djankov, McLiesh, and Shleifer (2005). The authors defined credit registries as databases managed by a government agency or a private organization that collect information on the standing of borrowers in the financial system with a view to making it available to actual and potential lenders.

Both rule of law and government effectiveness are taken from Kaufmann, Kraay, and Mastruzzi (2007). The former measures the extent to which agents have confidence in and abide by the rules of society, especially the quality of contract enforcement, the police, and the courts, as well as the likelihood of crime and violence. The latter assesses the quality of public services, the quality of policy formulation and implementation, and the credibility of the government's commitment to such policies. The two governance indicators range from 2.5 to 2.5 , with higher values corresponding to better governance.

Bureaucratic quality, an index calculated by the Political Risk Services Group, measures the ability of the bureaucracy to minimize revisions of policy when governments change. It ranges from 1 (low) to 4 (high). Because government effectiveness and bureaucratic quality are highly correlated with the rule of law, these variables are used alternatively in the regressions as a robustness check.

\footnotetext{
${ }^{6}$ The choice of period (1992-2006) is dictated by the availability of data on the institutional variables.
} 
Table 1 presents the difference of the averages of the data between CFA and non-CFA franc countries. CFA franc countries on average are not statistically different from the rest of SSA in terms of economic development (GDP per capita) or efforts to liberalize their financial sector. However, they have experienced lower inflation than other SSA countries. Despite this more favorable macroeconomic environment, credit to the private sector remains significantly lower. Consistent with our hypothesis, the indicators capturing the availability of information, property rights, and their enforcement are generally lower for the CFA zone.

Table 1. Test of Mean Differences Between CFA and non-CFA Franc Countries, 1992-2006

\begin{tabular}{lrrc}
\hline & CFA & Non-CFA & Difference \\
\hline & & & \\
Credit to private sector over GDP & 0.10 & 0.15 & $-0.05^{* *}$ \\
GDP per capita (\$US) & 851.2 & 913.4 & -62.2 \\
Inflation (log) & 0.1 & 0.3 & $-0.2^{* *}$ \\
Property rights & 36 & 44.9 & $-8.9^{* * *}$ \\
Information sharing (percent) & & & \\
$\quad$ Countries with credit bureaus & 57.6 & 21.6 & $36.0^{* * *}$ \\
$\quad$ Coverage (2008) & 2.5 & 8.8 & -3.8 \\
Financial liberalization & 58.5 & 58.1 & 0.4 \\
Rule of law & -0.9 & -0.7 & $-0.2^{*}$ \\
Government effectiveness & -0.8 & -0.6 & $-0.2^{*}$ \\
Bureaucracy & 1.1 & 1.4 & -0.3 \\
& & & \\
\hline
\end{tabular}

\footnotetext{
${ }^{1}$ Number of individuals and firms in percent of adults. Differences in the information coverage ratio is only significant at 12 percent, reflecting a larger disparity among non-CFA countries.

$*$ significant at $10 \%$; ** significant at $5 \%$; *** significant at $1 \%$.
}

\section{B. Methodology and Main Results}

To explain the level of financial development, a standard model where financial development depends on the level of economic development, macroeconomic conditions, and financial reform is extended to include variables capturing the availability of credit information and the quality of the legal environment. The model specification is as follows:

$$
F_{i, t}=\alpha_{0}+\alpha_{1} * \log \left(y_{i, t}\right)+\alpha_{2} * \log \left(1+\operatorname{Infl}_{i, t}\right)+\alpha_{3} * C F A+\alpha_{4} * F l_{i, t}+\alpha_{5} * X_{i, t}+u_{i}+v_{t}+\varepsilon_{i, t}
$$

where $F_{i, t}$ is the credit to the private sector-over-GDP ratio in country $i$ at time $t ; y$ stands for the per capita GDP; Infl represents the inflation rate; $C F A$ is a dummy variable for CFA franc countries; $F l_{i, t}$ is the financial liberalization index; $X$ is a set of institutional variables; $u_{i}$ is an unobserved country-specific effect; $v_{t}$ is a time dummy; and $\varepsilon_{i, t}$ is the error term.

A two-step Feasible Generalized Least Squares (FGLS) is used to estimate the model and address the problem of heteroscedasticity. This econometric approach makes it possible to 
estimate the impact of time-invariant variables while controlling for country-specific effects. This feature is particularly relevant for empirical models like the one used here, where the statistical significance of the coefficient of a CFA dummy variable is estimated and analyzed while additional variables capturing the institutional framework are introduced into the model. $^{7}$

Several model specifications are estimated (Table 2). As expected, the level of development, captured by per capita GDP, is positively associated with financial development across all the specifications. Higher income stimulates demand for financial services, and could also translate into higher savings, thus improving the ability of the financial system to extend credit to the private sector.

Table 2. Institutions and Financial Development in SSA Countries, 1992-2006

\begin{tabular}{|c|c|c|c|c|c|c|c|c|}
\hline & \multicolumn{8}{|c|}{ Feasible Generalized Least Squares } \\
\hline & (1) & (2) & (3) & (4) & $(5)$ & (6) & (7) & (8) \\
\hline GDP per capita (log) & $\begin{array}{l}0.037 \\
(5.03)^{* * *}\end{array}$ & $\begin{array}{l}0.030 \\
(4.02)^{* * *}\end{array}$ & $\begin{array}{l}0.035 \\
(4.64)^{* * *}\end{array}$ & $\begin{array}{l}0.032 \\
(3.71)^{* * * *}\end{array}$ & $\begin{array}{l}0.027 \\
(3.20)^{* * * *}\end{array}$ & $\begin{array}{l}0.024 \\
(2.84)^{* * *}\end{array}$ & $\begin{array}{l}0.026 \\
(4.16)^{* * *}\end{array}$ & $\begin{array}{l}0.017 \\
(1.66)^{*}\end{array}$ \\
\hline Inflation $(\log )$ & $\begin{array}{l}-0.037 \\
(2.08)^{* *}\end{array}$ & $\begin{array}{l}-0.022 \\
(2.29)^{* *}\end{array}$ & $\begin{array}{l}-0.013 \\
(2.02)^{* *}\end{array}$ & $\begin{array}{l}-0.018 \\
(1.61)\end{array}$ & $\begin{array}{l}-0.002 \\
(0.29)\end{array}$ & $\begin{array}{l}0.005 \\
(0.49)\end{array}$ & $\begin{array}{l}0.008 \\
(0.96)\end{array}$ & $\begin{array}{l}-0.010 \\
(1.12)\end{array}$ \\
\hline CFA & $\begin{array}{l}-0.027 \\
(3.15)^{* * *}\end{array}$ & $\begin{array}{l}-0.022 \\
(2.54)^{* *}\end{array}$ & $\begin{array}{l}0.000 \\
(0.01)\end{array}$ & $\begin{array}{l}-0.032 \\
(2.42)^{* *}\end{array}$ & $\begin{array}{l}0.010 \\
(0.99)\end{array}$ & $\begin{array}{l}0.010 \\
(0.59)\end{array}$ & $\begin{array}{l}0.008 \\
(0.58)\end{array}$ & $\begin{array}{l}-0.004 \\
(0.25)\end{array}$ \\
\hline Financial liberalization & & $\begin{array}{l}0.002 \\
(6.50)^{* * *}\end{array}$ & $\begin{array}{l}0.002 \\
(6.70)^{* * *}\end{array}$ & $\begin{array}{l}0.002 \\
(5.33)^{* * * *}\end{array}$ & $\begin{array}{l}0.002 \\
(5.61)^{* * *}\end{array}$ & $\begin{array}{l}0.002 \\
(3.81)^{* * *}\end{array}$ & $\begin{array}{l}0.002 \\
(4.50)^{* * *}\end{array}$ & $\begin{array}{l}0.001 \\
(2.31)^{* *}\end{array}$ \\
\hline Property rights & & & $\begin{array}{l}0.002 \\
(3.74) * * *\end{array}$ & & & $\begin{array}{l}0.002 \\
(2.25)^{* *}\end{array}$ & $\begin{array}{l}0.001 \\
(2.04)^{* *}\end{array}$ & $\begin{array}{l}0.001 \\
(1.97)^{* *}\end{array}$ \\
\hline Information sharing & & & & $\begin{array}{l}0.041 \\
(2.22)^{* *}\end{array}$ & & $\begin{array}{l}0.038 \\
(1.75)^{*}\end{array}$ & $\begin{array}{l}0.030 \\
(1.67)^{*}\end{array}$ & $\begin{array}{l}0.064 \\
(3.33)^{* * * *}\end{array}$ \\
\hline Rule of law & & & & & $\begin{array}{l}0.039 \\
(3.93)^{* * * *}\end{array}$ & $\begin{array}{l}0.030 \\
(2.01)^{* *}\end{array}$ & & \\
\hline Government effectiveness & & & & & & & $\begin{array}{l}0.066 \\
(4.72)^{* * *}\end{array}$ & \\
\hline Bureaucracy quality & & & & & & & & $\begin{array}{l}0.001 \\
(0.14)\end{array}$ \\
\hline Constant & $\begin{array}{l}-0.100 \\
(2.27)^{* *}\end{array}$ & $\begin{array}{l}-0.226 \\
(3.55)^{* * *}\end{array}$ & $\begin{array}{l}-0.268 \\
(4.57)^{* * *}\end{array}$ & $\begin{array}{l}-0.234 \\
(3.56)^{* * * *}\end{array}$ & $\begin{array}{l}-0.193 \\
(2.94)^{* * *}\end{array}$ & $\begin{array}{l}-0.182 \\
(2.72)^{* * * *}\end{array}$ & $\begin{array}{l}-0.141 \\
(2.72)^{* * * *}\end{array}$ & $\begin{array}{l}-0.142 \\
(2.00)^{* *}\end{array}$ \\
\hline Observations & 117 & 93 & 86 & 93 & 93 & 86 & 86 & 70 \\
\hline Number of countries & 40 & 33 & 33 & 33 & 33 & 33 & 33 & 26 \\
\hline Chi square (Wald test) & 48.3 & 67.7 & 117.8 & 57.1 & 102.5 & 79.4 & 137.7 & 48.3 \\
\hline
\end{tabular}

Notes: Data are averaged over five years. Absolute value of robust $t$ statistics in brackets; * significant at $10 \%$; ** significant at $5 \%$; *** significant at $1 \%$.

The results suggest that financial liberalization is positively associated with deeper financial markets. In line with McDonald and Schumacher (2007), one would expect that easing interest rate ceilings, lowering reserve requirements and entry barriers, and reducing government involvement in credit allocation decisions would promote financial development.

\footnotetext{
${ }^{7}$ Right-hand-side (institutional) variables exhibit relatively little variation across time. A random effects estimation may therefore be preferable because fixed effects methods can lead to imprecise estimates (Wooldridge, 2002), if the right-hand-side variables are not correlated with the error term: an assumption that the Hausman test statistic could not reject.
} 
Also consistent with the literature, inflation has a negative effect on financial development, though this effect is significant only in some specifications.

Several specifications related to the legal environment were examined. The model was first estimated by including a dummy variable for CFA franc countries to capture their French legal heritage (column 1). The coefficient on this variable is negative and significant. A gap in financial depth between CFA and non-CFA areas cannot be explained even after controlling for the level of economic development, macroeconomic stability, and financial liberalization. This result is consistent with previous findings that countries whose legal systems are inspired by French institutions have been on average less successful in promoting financial development.

The stability of this result was tested by estimating the model over a fiveyear rolling window for 1992-2006 using annual observations. The finding was that the coefficient of the CFA variable was not constant over time but deteriorated. This observation would suggest that legal origin cannot be the only factor accounting for the financial development gap between CFA franc and other SSA countries. Timevariant factors have probably deteriorated, hampering the

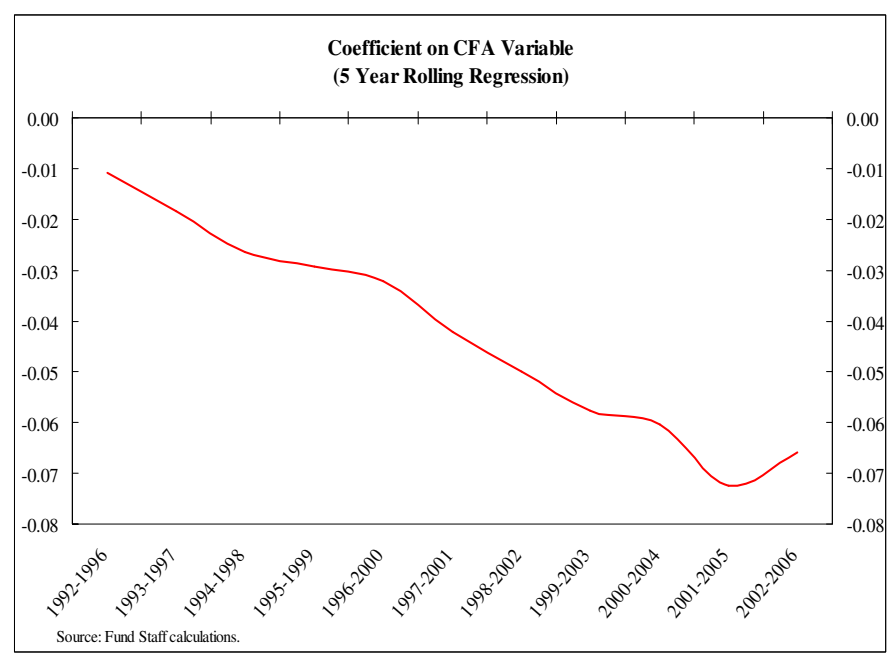
development of the financial sector in CFA countries.

To examine this hypothesis, variables capturing the availability of credit information, the strength of property rights, and their enforcement were added to the model (Table 2, columns 3, 4, and 5). The coefficients on these variables show the expected signs and are significantly associated with the level of financial development. With a similar level of financial liberalization and similar macroeconomic conditions, countries that better protect property rights, encourage information sharing, and promote the rule of law are likely to have deeper financial systems.

Interestingly, the coefficient related to the CFA variable is no longer significant when controlling for property rights or rule of law, two institutional aspects in which CFA countries underperformed. ${ }^{8}$ This result is confirmed when the three institutional variables are jointly included in the regression (column 6).

\footnotetext{
${ }^{8}$ The coefficient on the CFA variable is, nevertheless, negative and significant after controlling for information sharing. This variable captures the presence of credit bureaus, but does not take into account the coverage, because time series data on the coverage of credit registries was not being available throughout the period under study.
} 
Alternative measures for legal enforcement were used to test for the robustness of the results. Replacing rule of law with government effectiveness and the bureaucratic quality index left the results broadly unchanged (columns 7 and 8). To address the endogeneity issue, regressions were run using the lagged values of GDP per capita and inflation. The results (see Table 3) confirm the positive correlation between legal institutions and financial development. Finally, given the 50 percent devaluation in the CFA franc in 1994, GDP per capita in purchasing power parity terms is used to capture differences in level of development. The results are not qualitatively different.

Table 3. Institutions and Financial Development in SSA Countries: Instrumental Variable Approach, 1992-2006

\begin{tabular}{|c|c|c|c|c|c|c|c|c|}
\hline & \multicolumn{8}{|c|}{ Feasible Generalized Least Squares (Instrumental Variable) } \\
\hline & $(1)$ & $(2)$ & (3) & $(4)$ & $(5)$ & $(6)$ & $(7)$ & $(8)$ \\
\hline Lagged GDP per capita $(\log )$ & $\begin{array}{l}0.041 \\
(5.15)^{* * *}\end{array}$ & $\begin{array}{l}0.034 \\
(4.43)^{* * *}\end{array}$ & $\begin{array}{l}0.041 \\
(5.92)^{* * *}\end{array}$ & $\begin{array}{l}0.041 \\
(4.57)^{* * *}\end{array}$ & $\begin{array}{l}0.037 \\
(4.43)^{* * *}\end{array}$ & $\begin{array}{l}0.031 \\
(3.52)^{* * *}\end{array}$ & $\begin{array}{l}0.032 \\
(4.91)^{* * *}\end{array}$ & $\begin{array}{l}0.023 \\
(2.25)^{* *}\end{array}$ \\
\hline Lagged Inflation (log) & $\begin{array}{l}-0.060 \\
(4.13)^{* * *}\end{array}$ & $\begin{array}{l}-0.050 \\
(7.83)^{* * * *}\end{array}$ & $\begin{array}{l}-0.037 \\
(4.89)^{* * *}\end{array}$ & $\begin{array}{l}-0.039 \\
(3.78)^{* * * *}\end{array}$ & $\begin{array}{l}-0.004 \\
(0.30)\end{array}$ & $\begin{array}{l}0.001 \\
(0.05)\end{array}$ & $\begin{array}{l}0.007 \\
(0.60)\end{array}$ & $\begin{array}{l}-0.027 \\
(2.27)^{* *}\end{array}$ \\
\hline CFA & $\begin{array}{l}-0.034 \\
(3.72)^{* * * *}\end{array}$ & $\begin{array}{l}-0.029 \\
(3.04) * * *\end{array}$ & $\begin{array}{l}-0.016 \\
(1.55)\end{array}$ & $\begin{array}{l}-0.042 \\
(3.25)^{* * * *}\end{array}$ & $\begin{array}{l}0.009 \\
(0.84)\end{array}$ & $\begin{array}{l}0.006 \\
(0.35)\end{array}$ & $\begin{array}{l}0.011 \\
(0.70)\end{array}$ & $\begin{array}{l}-0.014 \\
(0.81)\end{array}$ \\
\hline Financial liberalization & & $\begin{array}{l}0.002 \\
(5.77)^{* * * *}\end{array}$ & $\begin{array}{l}0.002 \\
(6.38)^{* * * *}\end{array}$ & $\begin{array}{l}0.002 \\
(5.12)^{* * * *}\end{array}$ & $\begin{array}{l}0.002 \\
(5.40)^{* * *}\end{array}$ & $\begin{array}{l}0.001 \\
(3.35)^{* * *}\end{array}$ & $\begin{array}{l}0.002 \\
(4.55)^{* * * *}\end{array}$ & $\begin{array}{l}0.001 \\
(1.89)^{*}\end{array}$ \\
\hline Property rights & & & $\begin{array}{l}0.001 \\
(2.69)^{* * * *}\end{array}$ & & & $\begin{array}{l}0.001 \\
(1.74)^{*}\end{array}$ & $\begin{array}{l}0.001 \\
(1.59)\end{array}$ & $\begin{array}{l}0.001 \\
(1.84)^{*}\end{array}$ \\
\hline Information sharing & & & & $\begin{array}{l}0.048 \\
(2.73) * * *\end{array}$ & & $\begin{array}{l}0.038 \\
(1.93)^{*}\end{array}$ & $\begin{array}{l}0.025 \\
(1.43)\end{array}$ & $\begin{array}{l}0.069 \\
(3.64)^{* * * *}\end{array}$ \\
\hline Rule of law & & & & & $\begin{array}{l}0.041 \\
(4.21)^{* * * *}\end{array}$ & $\begin{array}{l}0.037 \\
(2.55)^{* *}\end{array}$ & & \\
\hline Government effectiveness & & & & & & & $\begin{array}{l}0.071 \\
(5.40)^{* * *}\end{array}$ & \\
\hline Bureaucracy quality & & & & & & & & $\begin{array}{l}-0.002 \\
(0.19)\end{array}$ \\
\hline Corruption & & & & & & & & \\
\hline Constant & $\begin{array}{l}-0.107 \\
(2.36)^{* *}\end{array}$ & $\begin{array}{l}-0.159 \\
(3.06)^{* * *}\end{array}$ & $\begin{array}{l}-0.363 \\
(6.16)^{* * *}\end{array}$ & $\begin{array}{l}-0.214 \\
(3.82)^{* * *}\end{array}$ & $\begin{array}{l}-0.165 \\
(3.09)^{* * *}\end{array}$ & $\begin{array}{l}-0.222 \\
(3.20)^{* * *}\end{array}$ & $\begin{array}{l}-0.209 \\
(3.66)^{* * *}\end{array}$ & $\begin{array}{l}-0.156 \\
(1.87)^{*}\end{array}$ \\
\hline Observations & 116 & 92 & 85 & 92 & 92 & 85 & 85 & 70 \\
\hline Number of countries & 40 & 33 & 33 & 33 & 33 & 33 & 33 & 26 \\
\hline Chi square (Wald test) & 63.9 & 385.0 & 327.1 & 113.8 & 102.4 & 72.6 & 131.4 & 73.5 \\
\hline
\end{tabular}

Notes: Data are averaged over five years. Absolute value of robust $t$ statistics in brackets; * significant at $10 \%$; ** significant at 5\%; *** significant at $1 \%$.

\section{Summary AND CONCLUSIONS}

Deepening the financial sector is a complex process that goes beyond mere economic factors. This paper has examined the reasons why financial sectors in the CFA franc countries are shallow and traced them back to a lack of progress in improving the availability of creditor information and protecting investors. While financial liberalization and macroeconomic stability are necessary conditions for financial deepening, they are not sufficient. In this regard, the results of this paper are consistent with a growing body of literature underscoring the role of legal factors in financial development. 
The main policy implications are that expanding creditor information and strengthening creditor rights in CFA franc countries deserve more attention. These, however, are equally complex processes. The coverage of existing credit bureaus should be extended and include as much information as possible on the repayment profile of customers. This must be achieved while preserving an appropriate degree of privacy and safeguarding sensitive information. Strengthening creditor rights would require changes in legislation governing debt collection and collateral. Some reforms may have regional as well as national dimensions. Legislation on debt recovery would depend in turn on efficient property registration and land surveying in both cities and countryside. Finally, reform of the courts is vital for improving enforcement.

Further work to refine the analysis in this paper could thus include the study of country cases where such improvements have been achieved. Although this paper has indicated that the legal heritage is not time-invariant and policy-independent, legal origin nevertheless sets boundaries on the extent of possible institutional reforms. 


\section{REFERENCES}

Acemoglu, Daron, and Simon Johnson, 2005, "Unbundling Institutions," Journal of Political Economy, Vol. 113, pp. 949-95.

Beck, Thorsten, and Ross Levine, 2003, "Legal Institutions and Financial Development," World Bank Policy Research Working Paper No. 3136 (Washington: World Bank).

Bester, H., 1985, "Screening Versus Rationing in Credit Markets with Imperfect Information," American Economic Review, Vol. 75 (September), pp. 850-55.

Bester, H., 1987, "The Role of Collateral in Credit Markets with Imperfect Information," European Economic Review, Vol. 31 (June), pp. 887-99.

Boyd, John, Ross Levine, and Bruce D. Smith, 2001, “The Impact of Inflation on Financial Sector Performance," Journal of Monetary Economics, Vol. 47, pp. 221-48.

Cottarelli, Carlo, Giovanni Dell'Ariccia, and Ivanna Vladkova-Hollar, 2003, "Early Birds, Late Risers, and Sleeping Beauties: Bank Credit Growth to the Private Sector in Central and Eastern Europe and the Balkans," IMF Working Paper WP/03/213 (Washington: International Monetary Fund).

Dehesa, Mario, Pablo Druck, and Alexander Plekhanov, 2007, "Relative Price Stability, Creditor Rights, and Financial Deepening," IMF Working Paper WP/07/139 (Washington: International Monetary Fund).

Detragiache, Enrica, Poonam Gupta, and Thierry Tressel, 2005, "Finance in Lower-Income Countries: An Empirical Exploration,” IMF Working Paper WP/05/167 (Washington: International Monetary Fund).

Devinney, T. M., 1986, Rationing in a Theory of the Banking Firm (Berlin, Springer-Verlag).

Djankov, Simeone, Carales McLiesh, and Andrei Shleifer, 2005, "Private Credit in 129 Countries," National Bureau of Economic Research Working Paper No. 11078 (Cambridge, MA: NBER).

Gelbard, Enrique, and Sergio Leite, 1999, "Measuring Financial Development in SubSaharan Africa,” IMF Working Paper WP/99/105 (Washington: International Monetary Fund).

Gulde, Anne-Marie, Catherine Patillo, and Jakob Christensen, 2006, Sub-Saharan Africa: Financial Sector Challenges (Washington: International Monetary Fund).

Huybens, E., and Bruce Smith, 1998, "Financial Markets Frictions, Monetary policy, and Capital Accumulation in a Small Open Economy," Journal of Economic Theory, Vol. 81, pp. 353-400. 
1999, “Inflation, Financial Markets, and Long Run Real Activity,” Journal of Monetary Economics, Vol. 43, pp. 283-315.

Kaufmann, Daniel, Aart Kraay, and Massimo Mastruzzi, 2007, “Governance Matters VI: Aggregate and Individual Governance Indicators, 1996-2006," Policy Research Working Paper Series 4280 (Washington: World Bank).

La Porta, Rafael, Florencio Lopez-de-Silanes, Andrei Shleifer, and Robert Vishny, 1998, "Law and Finance," Journal of Political Economy, Vol. 106, No. 6, pp. 1113-55.

McDonald, Calvin, and Liliana Schumacher, 2007, "Financial Deepening in Sub-Saharan Africa: Empirical Evidence on the Role of Creditor Rights Protection and Information Sharing," IMF Working Paper, WP/07/203.

Mehran, Hassanali, Piero Ugolini, Jean Philippe Briffaus, George Iden, Tonny Lybek, Stephen Swaray, and Peter Hayward, 1998, "Financial Sector Development in SubSaharan African Countries," IMF Occasional Paper 169 (Washington: International Monetary Fund).

Sacerdoti, Emilio, 2005, "Access to Bank Credit in Sub-Saharan Africa: Key Issues and Reform Strategies,”, IMF Working Paper, WP/05/166 (Washington: International Monetary Fund).

Singh, Raju J., 1992, "An Imperfect Information Approach to the Structure of the Financial System," UNCTAD Discussion Paper No. 46 (Geneva: UNCTAD).

, 1994, "Bank Credit, Small Firms, and the Design of a Financial System for Eastern Europe,” UNCTAD Discussion Paper No. 86 (Geneva: UNCTAD). , 1997, "Banks, Growth, and Geography,” UNCTAD Discussion Paper No 127 (Geneva: UNCTAD).

Stiglitz, Joseph E., and Andrew Weiss, 1981, "Credit Rationing in Markets with Imperfect Information," American Economic Review, Vol. 71, pp. 393-410.

Tressel, Thierry, and Enrica Detragiache, 2008, "Do Financial Sector Reforms Lead to Financial Development? Evidence from a New Dataset," IMF Working Paper WP/08/265 (Washington: International Monetary Fund).

Wooldridge, Jeffrey, 2002, Econometric Analysis of Cross Section and Panel Data (Cambridge, MA: MIT Press). 
Annex 1. Summary Statistics

Table 1. Descriptive Statistics, 1992-2006

\begin{tabular}{lrrrrr}
\hline \multicolumn{1}{c}{ Variable } & Observations & Mean & $\begin{array}{l}\text { Standard } \\
\text { deviation }\end{array}$ & Minimum Maximum \\
\hline & & & & & \\
Private credit over GDP & 117 & 0.13 & 0.13 & 0.00 & 0.70 \\
GDP per capita (log) & 135 & 6.07 & 1.07 & 4.31 & 8.89 \\
Inflation (log) & 121 & 0.19 & 0.49 & -0.02 & 4.14 \\
Property rights & 115 & 42.14 & 16.03 & 10.00 & 70.00 \\
Information sharing & 144 & 0.32 & 0.43 & 0.00 & 1.00 \\
Financial liberalization & 109 & 58.22 & 25.64 & 1.50 & 100.00 \\
Rule of law & 138 & -0.75 & 0.71 & -2.27 & 0.87 \\
Government effectiveness & 141 & -0.70 & 0.62 & -2.17 & 0.77 \\
Bureaucracy & 96 & 1.28 & 0.89 & 0.00 & 3.67 \\
& & & & & \\
\hline
\end{tabular}

Table 2. Correlation Matrix

\begin{tabular}{lrrrrrrrrrr}
\hline Variables & & 1 & 2 & 3 & 4 & 5 & 6 & 7 & 8 & 9 \\
\hline & & & & & & & & & & \\
Private credit over GDP & 1 & 1.00 & & & & & & & & \\
GDP per capita (log) & 2 & 0.47 & 1.00 & & & & & & & \\
Inflation (log) & 3 & -0.19 & -0.14 & 1.00 & & & & & & \\
Property rights & 4 & 0.38 & 0.31 & -0.13 & 1.00 & & & & & \\
Information sharing & 5 & 0.08 & -0.05 & -0.16 & -0.04 & 1.00 & & & & \\
Financial liberalization & 6 & 0.41 & 0.34 & -0.32 & 0.01 & -0.06 & 1.00 & & & \\
Rule of law & 7 & 0.56 & 0.51 & -0.34 & 0.74 & 0.05 & 0.32 & 1.00 & & \\
Government effectiveness & 8 & 0.62 & 0.51 & -0.30 & 0.63 & 0.18 & 0.33 & 0.87 & 1.00 & \\
Bureaucracy & 9 & 0.32 & 0.55 & -0.03 & 0.46 & 0.19 & -0.04 & 0.50 & 0.59 & 1.00 \\
& & & & & & & & & & \\
\hline
\end{tabular}




\section{Annex 2. Variable Definitions and Sources}

\begin{tabular}{ll}
\hline Variable & Definition \\
\hline Private credit over GDP & Private credit by deposit money banks to GDP. \\
GDP per capita & $\begin{array}{l}\text { Nominal gross domestic product divided by } \\
\text { the size of the population. }\end{array}$ \\
Inflation & Change in consumer price index (CPI).
\end{tabular}

Property rights

Information sharing

Financial liberalization

Rule of law

Government effectiveness

Bureaucracy

Credit registry coverage
An index measuring the ability of individuals to accumulate private property, secured by clear laws that are fully enforced by the state.

A dummy variable recording the presence of

An aggregate index capturing whether interest rates are liberalized or not, the number of years real lending and deposit rates have been positive, the existence of significant informal financial sectors and presence of directed credit allocation mechanisms.

A score measuring the extent to which agents have confidence in and abide by the rules of society, and in particular the quality of contract enforcement, the police, and the courts, as well as the likelihood of crime and violence

A score measuring the quality of public services, the quality of the civil service and the degree of its independence from political pressures, the quality of policy formulation and implementation, and the credibility of the government's commitment to such policies

An index capturing the ability of the bureaucracy to minimize revisions of policy when governments change.

The number of individuals and firms listed by credit bureaus with current information on repayment history, unpaid debts or credit outstanding. The number is expressed as a percentage of the adult population. either public or private credit registries

\section{Source}

Financial Structure Database (2007), and International Financial Statistics (2007)

International Financial Statistics (2007)

International Financial Statistics (2007)

Heritage Foundation database (2007)

Djankov, McLiesh, and Shleifer (2005)

McDonald and Schumacher (2007)

Kaufmann, Kraay and Mastruzzi (2007)

Kaufmann, Kraay and Mastruzzi (2007)

Political Risk Services database (2008)

Doing Business database (2008) 